\title{
"The management accounting and the business strategy development at SMEs"
}

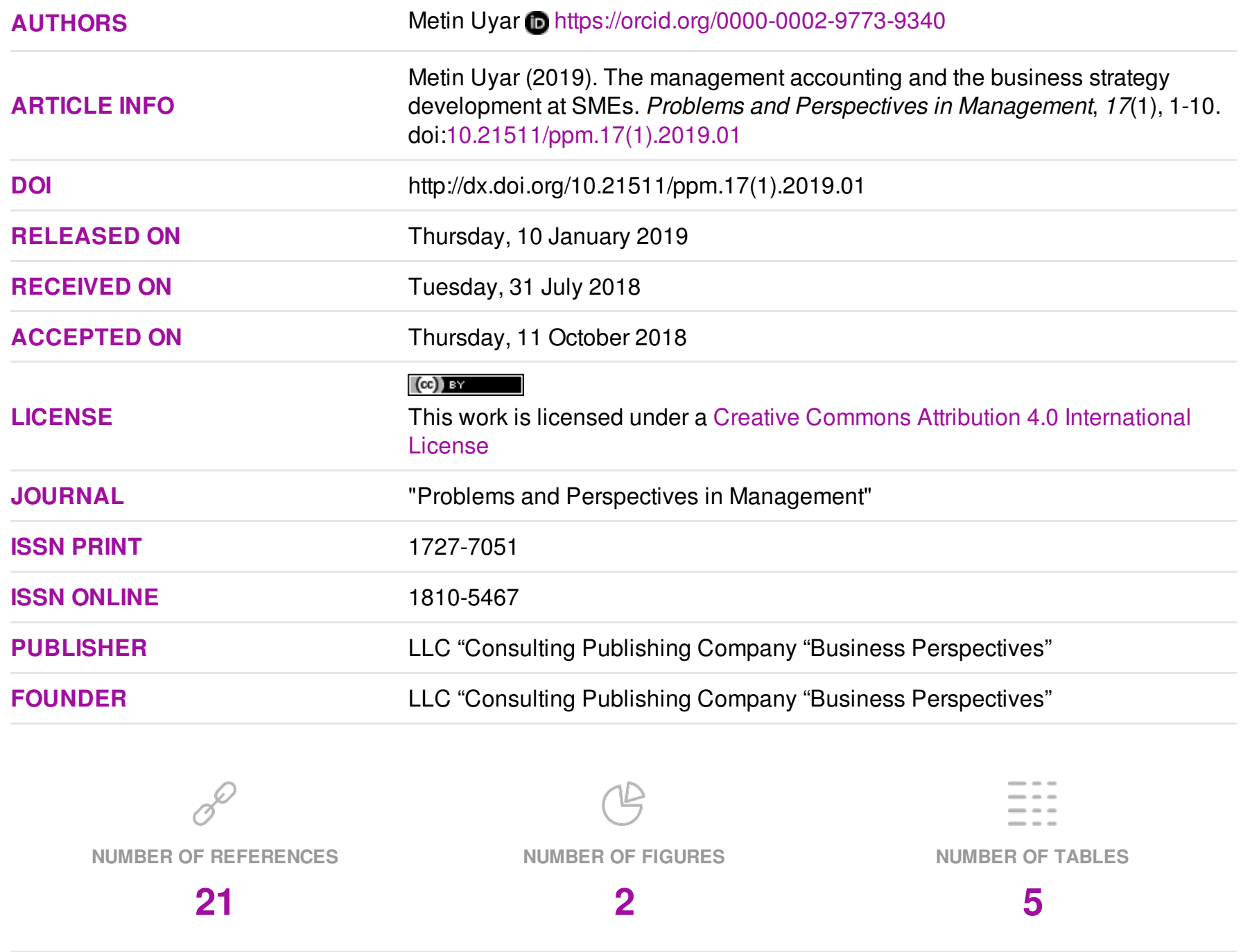

(c) The author(s) 2023. This publication is an open access article. 


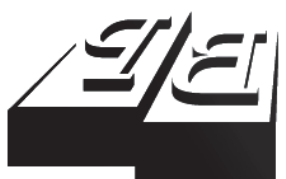

BUSINESS PERSPECTIVES

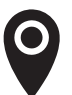

LLC "CPC "Business Perspectives" Hryhorii Skovoroda lane, 10, Sumy, 40022, Ukraine

www.businessperspectives.org

Received on: $31^{\text {st }}$ of July, 2018 Accepted on: $11^{\text {th }}$ of October, 2018

(C) Metin Uyar, 2019

Metin Uyar, Ph.D., Assistant Professor of International Business and Trade, Faculty of Economics Administrative and Social Sciences Istanbul Gelişim University, Turkey.

\section{(c) (i)}

This is an Open Access article, distributed under the terms of the Creative Commons Attribution 4.0 International license, which permits unrestricted re-use, distribution, and reproduction in any medium, provided the original work is properly cited.

Metin Uyar (Turkey)

\title{
THE MANAGEMENT ACCOUNTING AND THE BUSINESS STRATEGY DEVELOPMENT AT SMES
}

\begin{abstract}
The purpose of this study is to determine the relationship between management accounting practices and strategy development in SMEs. SMEs are among the main actors of economic development and growth. To determine the right strategies in a variable and competitive market, the qualitative and quantitative knowledge produced by the accounting system is needed. The management accounting system can influence managerial decisions, change strategies, and affect the performance of the firm through its extensive practices. Using the multivariate statistical analyses, the results of the applied studies for SMEs show that the management accounting system's planning and control, cost management, and performance measurement and evaluation functions significantly affect which strategy the firms will implement. According to the research, the management accounting practices used by SMEs are related to the company strategies they have taken, and these actions have been reached as an effect on the strategies of the companies.
\end{abstract}

\section{Keywords}

JEL Classification $\quad$ M40, M41, M49

\section{INTRODUCTION}

Accounting has become a future-oriented information system rather than a history-based record keeping mechanism with the transformation it has undergone. This transformation increases the share in the amount of data that businesses need to make decisions and develop strategies. Management accounting opens the way for businesses to bridge between the past and the future through the methods and techniques they contain. A lot of research shows that the strategic management accounting approach in accounting is getting stronger (Juras, 2014; Alnawaiseh, 2013). According to Anderson and Lanen (1999), management accounting has three main functions. These are cost management, planning and control, and finally performance measurement and evaluation. Planning and control is one of the three basic functions of the management accounting system, it affects businesses' forecasting of the future and their management priorities. The control function allows the company to update the roadmap of the company by determining whether the works overlap with the objectives. Developing a strategy is a process that requires considerable attention and information. Establishing the right strategies for businesses is linked to using the right information resource. Management accounting does not only generate the knowledge needed to develop strategies, but also controls the success of the activities. In this context, the management accounting establishes the substructure of strategy development in firms. Abdel Al and McLellan (2013) emphasize that management accounting practices must be supported by organiza- 
tional design and organizational factors such as effective production processes in strategy development from a holistic perspective.

The research aims to provide a perspective based on management accounting for practitioners, accounting staff, and researchers, examining the possible impacts of management accounting on strategy development. The study is very important for the evaluation of small and medium-sized enterprises (SMEs) from basic units of economic and social development and for determination of a current situation. Analysing the sub-factors and basic functions of management accounting practices in detail will help small and medium-sized enterprises to increase productivity and efficiency in resource use that affects strategy success. One of the most important contributions of this study is being one of the first studies evaluating the relationship between management accounting and strategy development at SMEs from the perspective of control and planning. The study establishes an infrastructure for studies on management accounting and strategy development. Another contribution of the study is that it categorizes SMEs according to the level of management accounting adaptation, thus helping them to determine more accurately the levels of use of management accounting practices in operations. Another important aspect of the study is the management accounting adaptation score generated by the regulation of place scales in the literature.

In the first part of the research, there are the literature review and hypotheses development in which the relations between variables are found and done. In the second chapter, there is presented an applied analysis for the determination of the research model developed in the conceptual framework over the SMEs.

\section{LITERATURE REVIEW AND HYPOTHESES}

\subsection{Management accounting practices}

Management accounting is a mechanism that contributes to achieving sustainability, making strategic decisions, and achieving competitive advantage. Management accounting as an information system enhances firm performance, profitability, and productivity (Baines \& LangfieldSmith, 2003; Chenhall \& Langfield-Smith, 1998). Budgeting, sales profitability analysis, quality improvement programs, product profitability analysis, benchmarking, customer profitability analysis, stakeholder value analysis, target costing, activity-based management, value chain analysis, product life cycle costing, quality costs help to improve business performance. These tools are used to achieve strategic competitive advantage when the intended use is taken into consideration. It can be denoted that the techniques in the management accounting are used for two purposes in general. The first is the use of these tools for strategic purposes (long-term) and the second is the use of cur- rent operations (short-term). Although both types of use are aimed at ultimately improving performance, the strategic priorities will be required depending on the intended use. In this direction, it is generally expected that the performance of firms will be influenced positively by management accounting practices. Chenhall and Langfield-Smith (1998) have attempted to explain how management techniques and management accounting practices that improve business performance under certain strategic priorities can be combined. They emphasized the importance of emphasizing product differentiation, low price strategies, or the merger of both. Recently developed management accounting practices are mainly financial and non-financial information that focuses on strategic direction (Angelakis et al., 2010). Analyses are being made on the worldwide adoption and impact of contemporary and traditional management accounting practices (Baird et al., 2004).

\subsection{Business strategies}

When developing a strategic business model, it is necessary to evaluate the principles of the strategy in the competition and industrial structure as strategic intellectual inputs. The main assumptions of 
this competition start with how firms compete and how goods and services are designed. For this reason, it focuses on factors such as business strategy, level of competition and product/service design capability. Competition strategies can be categorized as low-cost (cost leadership) strategies and differentiation strategies. In the low-cost strategy, it is necessary to be a company, which is trying to be the lowest cost producer in the sector in the activities of the enterprises. Abraham et al. (2008) explain that the notion of competitive advantage also gives the firm that gains cost leadership a potential for super profitability. This includes firms evaluating the potential benefits of technology, including better utilization of input source efficiency and scale economies. Businesses that implement cost leadership increase their profitability by offering their goods near or below the price offered by their competitors.

The differentiation strategy is a strategy based on the firm's superiority over its competitors by offering unique or superior values to customers on issues such as product quality, features, or after-sales services. Instead of continuing to focus on differentiation, firms are not advised to maintain unique discipline and reinforce cost leadership (Acquaah \& Yasai-Ardekani, 2008). As a matter of fact, according to Box and Miller (2011), small firms adopting differentiation have reached the most successful strategy. Differentiation is to produce something which is regarded as unique by everyone by differentiating the goods or services that the companies have marketed. Bryson and Lombardi (2009) emphasize that companies studying two leading-edge companies can achieve a differentiation or a combination of value targeting the niche market could be a separate combined business strategy. Yan (2010) and Parners (2011) emphasized the importance of competition strategies for the sustainability of the manufacturers. The necessity of competition strategies is emphasized to increase the competitive advantage and performance of the enterprises in the study. Cost leadership, which plays a key role for small and large businesses, enables implementation of competitive strategies such as differentiation and innovation, adaptation to the dynamic environment, competitive advantage and increased firm performance. In addition to these, Acquaah and YasaiArdekani (2008) emphasized that cost leadership would be more beneficial than product differentiation strategy in the long run.

\subsection{Relations between variables and hypotheses}

Cuganesan et al. (2012) noted that empirical management accounting research has paid insufficient attention to the implementation through which strategizing occurs. They have also seen the importance of management in the public sector. These are investigated in specific ways. Their study also suggests that the scholars may take a specific approach for accounting research agenda. Rickwood et al. (1990) asserted the role of management accounting in a company in reaction to threats in the market. Their paper examines the impacts of a company's management accounting practices on the company strategy development process. The role of the management accountant is to extend beyond the routine provision of accounting information to include the preparation of special records that make him a dominant member of the decision-making team (Oboh \& Ajibolade, 2017). Cadez and Guilding (2008) examined the adoption of strategic management accounting practices. They also measured the impact of management accounting practices on business performance. They have reported the adoption rates of management accounting practices in manufacturing industries in different sectors and have implemented a moderator exchange on whether these businesses are classified as advanced and non-industrial. The research shows that there is a positive and significant relationship between management accounting practices and strategy development. As a result, to achieve higher performance, advanced management accounting techniques should be used.

The hypotheses of researching in the direction of the evaluations made are as follows:

H1: Management accounting practices have a positive effect on which strategies are used in SMEs.

H1a: The planning and control sub-dimension of the management accountant is positively changing the strategy of differentiation of the enterprises. 
H1b: The cost management sub-factor positively influences the selection of the differentiation strategy.

H1c: The performance measurement and evaluation sub-dimension positively affect companies' differentiation strategy development.

H1d: The planning and control sub-dimension positively affects the selection of the low-cost strategy.

H1e: Cost management has a positive effect on businesses and the selection of the low-cost strategy.

H2: The level of competition intensity of SMEs significantly affects company strategies.

H2a: Competitive intensity level positively influences the selection of differentiation strategy.

H2b: Competitive intensity has a positive effect on the choice of low-cost strategy.

H3: Management accounting practices and level of intensity of competition together are positively affecting the strategy development of enterprises.

H4: Financial performance moderates the impact of management accounting and the intensity of competition on the determination of firm strategies.

The theoretical model used in this research is as follows.

\section{METHODS}

The methodology section consists of two parts. First, the sample selection is explained. Second, the design of the measuring tool is described.

\subsection{Sampling}

The data of this research, which examines the relationship between management accounting and firm strategies, were compiled using the questionnaire method. SMEs ${ }^{1}$ who have been working in Istanbul as have been taken because of limited accessibility of the firm and low research budget utilized for financing this research as a sample. The questionnaire prepared for the research was submitted to the managers and accounting staff who run in accounting department of SMEs and it was determined that the information set supplied from 117 companies had the qualifications necessary for analysis and evaluation. There are 41 firms with 10-25 employees, 28 firms with 26-40 employees, 13 firms with 41-55 employees and 18 firms with 56-70 employees. There are 11 companies with employees from 71 to 85 of the participants and 6 from 86 to 100 staff. 34 of the participants are in managerial position and 83 of them are in accounting staff position. There are 79 firms with an asset value between 1 and 5 million euros in terms of total assets, and 38 firms with an asset value between 6 and 10 million euros.

\subsection{Measurement tools}

There are two basic variables in the research, namely management accounting practices and firm strategy. There are also control variables

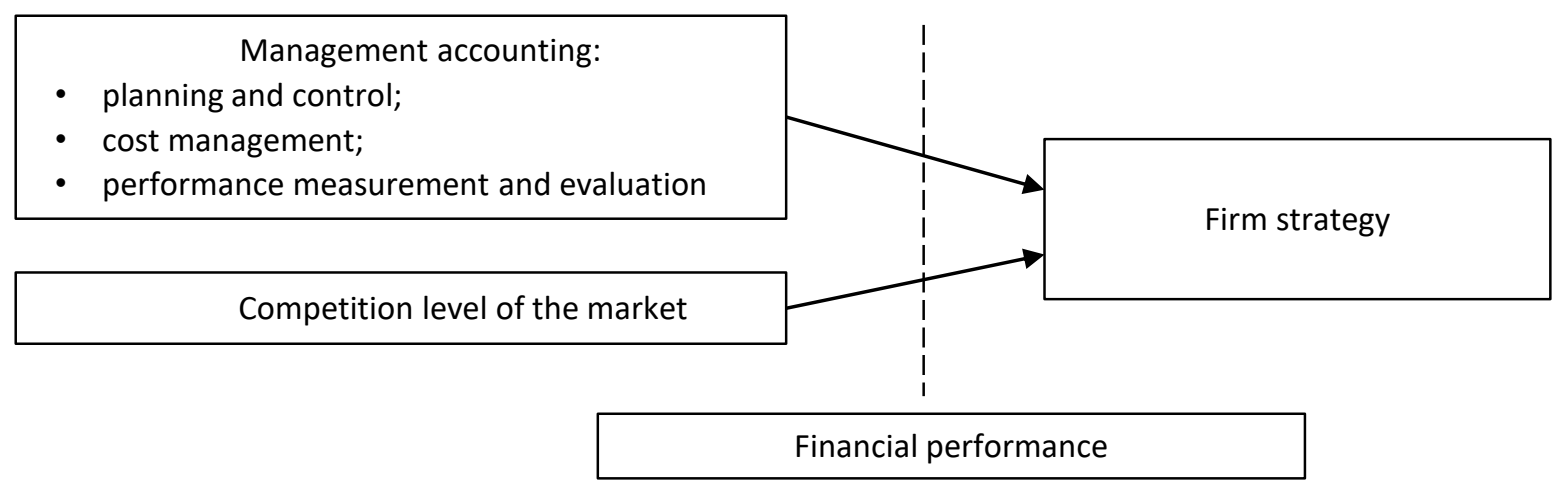

Figure 1. Structural model of the research

1 The Official Gazette released on June 24, 2018 declared the definition of SMEs in Turkey in the following way: number of employees < 10 - micro-enterprises, number of employees $<50$ - small enterprises, number of employees $<250$ - medium-sized enterprises. 
Table 1. Factor analysis and reliability values of variables

\begin{tabular}{|c|c|c|c|c|c|}
\hline Factor & $\mu$ & $\sigma$ & KMO & $\begin{array}{c}\text { Average } \\
\text { load factor }\end{array}$ & Cronbach $\alpha$ \\
\hline \multicolumn{6}{|c|}{ Management accounting } \\
\hline a) Planning and control (6 items) & 3.81 & 0.24 & 0.83 & 0.74 & 0.78 \\
\hline b) Cost management (5 items) & 3.06 & 0.35 & 0.72 & 0.64 & 0.70 \\
\hline c) Performance measurement and evaluation (11 items) & 3.20 & 0.62 & 0.80 & 0.70 & 0.74 \\
\hline \multicolumn{6}{|c|}{$\begin{array}{ll}\text { Company strategies } \\
\end{array}$} \\
\hline a) Low cost (4 items) & 3.59 & 0.38 & 0.79 & 0.75 & 0.72 \\
\hline b) Differentiation (5 items) & 3.13 & 0.44 & 0.73 & 0.61 & 0.68 \\
\hline c) Competition (5 items) & 4.28 & 0.46 & 0.85 & 0.77 & 0.75 \\
\hline
\end{tabular}

such as competition and firm financial performance. To measure the management accounting practices, categorization of Anderson and Lanen (1999, p. 379) and Atkinson et al. (2016) was used. In these works, management accounting applications are divided into three categories: planning and control, cost management and finally performance measurement and evaluation. The practices were listed, and the participants evaluated the degree to which they were used in the management accounting practices in this list with a fivepoint Likert scale. The scores obtained from the responses were divided into three different clusters: low adaptation firms, medium adaptation firms and high adaptation firms. Thus, it has been determined at what intensity firms apply management accounting practices. Company strategies are based on the scale of Abdel Al and McLellan (2013). A total of 5 questions for measuring competition by Jansen et al. (2006) and Widener (2007, p. 784) were adapted to the study. In financial performance, the profitability ratio of sales and the return ratio of capital are used.

\section{RESULTS}

The factor analysis, correlation analysis, and partial least squares methods were used in the statistical process. Table 1 contains the standardized load factor of the variables and the reliability of the factor structures. According to the values obtained in factor analysis, management accounting practices are divided into three sub-factors: planning and control, cost management, performance measurement and evaluation. Strategic options have emerged in two sub-dimensions: low cost strategies and differentiation strategies. The components of the competition factor are concentrated under a single factor: reliability value for planning and control (Cronbach $\alpha=0.78$ ), reliability value for cost management (Cronbach $\alpha=0.70$ ), reliability value for performance measurement and evaluation (Cronbach $\alpha=0.74$ ), which are sub-dimensions of management accounting applications, respectively. The obtained parameters show that the theoretical evaluations made for management accounting applications are statistically significant. Arithmetic mean of planning and control sub-dimension of management accounting applications is found as 3.86, arithmetic mean of cost management is 3.06 and arithmetic mean of performance measurement and evaluation is 3.20. Reliability value $(C r=0.72)$ and variance $(C r=0.68)$ for low cost strategies are determined from firm strategies. In terms of KMO values, it is understood that factor structures are sufficient for analysis.

After the reliability was determined, validity analyses of the research scales were conducted. The AVE (Average Variance Extracted) score of the management accounting variable is 0.68 . Validity value for company strategies and competition is 0.56 and 0.62 .

Table 2 shows the results of the correlation analysis carried out to determine the linear relationships between the variables after the reliability and validity analyses. There are no multicollinearity problems, because the results in Table 2 show that there are moderate or low-level linear relationships among the variables. The relationship between planning and control variables and differentiation strategies $(r=0.36)$ was established. The relationship between low-cost strategy and planning and control $(r=0.35)$ was found. There is a relationship between planning and control variables and intensity of competition $(r=0.23)$. The relationship between the cost management sub-factor and the differentiation and low-cost strategies 
Table 2. Pearson correlations (one-way)

\begin{tabular}{|c|c|c|c|c|c|c|c|c|c|}
\hline Variables & $\mu$ & $\sigma$ & PLCO & COMN & PMEV & DFST & LCST & COMP & APSA \\
\hline PLCO & 3.81 & 0.24 & - & - & - & - & - & - & - \\
\hline COMN & 3.06 & 0.35 & $0.26^{* * *}$ & - & - & - & - & - & - \\
\hline PMEV & 3.20 & 0.62 & $0.28^{* * *}$ & $0.15^{* * *}$ & - & - & - & - & - \\
\hline DFST & 3.13 & 0.44 & $0.36^{* *}$ & $0.28^{* * *}$ & 0.11 & - & - & - & - \\
\hline LCST & 3.59 & 0.38 & $0.35^{* *}$ & $0.37^{* *}$ & $0.17^{* * *}$ & $-0.24^{* * *}$ & - & - & - \\
\hline COMP & 4.28 & 0.46 & $0.23^{* * *}$ & $0.40 * *$ & $0.23^{* * *}$ & $0,21^{* * *}$ & $0,25 * * *$ & - & - \\
\hline APSA & 9.46 & 0.30 & $0.23^{* * *}$ & $0.25^{* * *}$ & $0.28^{* * *}$ & $0.13 * * *$ & $0.20^{* * *}$ & $0.22 * * *$ & - \\
\hline AROA & 2.39 & 0.07 & $0.19^{* * *}$ & $0.20^{* * *}$ & 0.10 & $0.17^{* * *}$ & $0.21^{* * *}$ & $0.18^{* * *}$ & $0.34^{* *}$ \\
\hline
\end{tabular}

Notes: PLCO - Planning and Control, COMN - Cost Management, PMEV - Performance Measurement and Evaluation, DFST - Differentiation Strategy, LCST - Low-Cost Strategy, COMP - Competition Intensity, APSA - Average Net Profit/Gross Sales Ratio for last 2 years, AROE - Average Return on Equity for last 2 years. ${ }^{*} p<0.01 ;^{* *} p<0.05 ;{ }^{* * *} p<0.10$.

( $r=0.28$ and $r=0.35)$ was found. Performance measurement and evaluation sub-factor differentiation strategy are not in a significant relationship $(r=0.11)$ and statistically correlated with low-cost strategy variables $(r=0.17)$.

The partial least squares method (PLS) was used to test the hypotheses. The PLS method is suitable for the analysis of small samples. The results of the hypothesis tests are shown in Figure 2 and Table 3. Management accounting practices $\rightarrow$ value of variance $\left(R^{2}=0.54\right)$ belonging to firm strategies is found. This shows high effectiveness for the direct correlation model and means that the management accountant has independent variable qualities on SMEs strategies. It has been found that the management accountant has a positive and meaningfully acceptable direct effect on the strategies $(\gamma=0.65$ and $p=0.002)$. Hence, hypothesis 1 "Management accounting practices have a positive effect on which strategies are used in SMEs" is accepted. The variance value of the effect of competition on SME strategies $\left(R^{2}=0.31\right)$ was realized. Strategic direct effect of intensity of competition was found to be significant at the level of $\gamma=0.44$ and $p=0.003$. According to this result, hypothesis 2: "The level of competition intensity of SMEs significantly affects company strategies" is accept- ed. Management Accounting practices x competition $\rightarrow$ company strategies linkage is statistically accepted $(\gamma=0.74$ and $p=0.000)$. Management accounting practices and competition factors for SMEs are important factors that can make a common impact. The moderator is defined as the parameters $(\gamma=0.71$ and $p=0.000)$ of the variable financial performance that together with the independent variables bring about the effect. In this context, hypothesis 4: "Financial Performance moderates the effect of management accounting and the intensity of competition on the determination of firm strategies" is accepted.

After testing the theoretical model, sub-hypotheses were tested (see Table 4). The planning and control sub-dimension has an effect that can be considered significant on differentiation $(\beta=0.39)$. Cost management changes the differentiation positively and significantly, in this context, hypothesis $1 \mathrm{~b}$ is confirmed $(\beta=0.36)$. Performance measurement and evaluation do not have any effect on differentiation $(\beta=0.12)$. The most effective sub-factor on the differentiation strategy seems to be planning and control. The intensity of competition affects SMEs' choice of differentiation strategy $(\beta=0.41)$. On the other hand, the intensity of competition affects the low-cost strategy. The lev-

Table 3. Test of the research model and effects between variables

\begin{tabular}{|c|c|c|c|c|c|}
\hline Paths & $\begin{array}{l}\text { Direct } \\
\text { effect, } v\end{array}$ & effect, $v$ & $p$-value & $t$-value & $\boldsymbol{R}^{2}(\%)$ \\
\hline Management accounting practices $\rightarrow$ company strategies & 0.65 & - & $0.002 *$ & 22. 49 & 54 \\
\hline Competition $\rightarrow$ company strategies & 0.44 & - & $0.003^{*}$ & 15.73 & 31 \\
\hline $\begin{array}{l}\text { Management accounting x practices competition } \rightarrow \text { company } \\
\text { strategies }\end{array}$ & - & 0.74 & $0.000^{*}$ & 28.78 & 73 \\
\hline $\begin{array}{l}\text { Management accounting practices } x \text { competition) } x \text { financial } \\
\text { performance } \rightarrow \text { company strategies }\end{array}$ & - & 0.71 & $0.000^{*}$ & 24.50 & 72 \\
\hline
\end{tabular}

Note: degree of freedom: 14 ; chi-square 30.69 ; $p$-value: 0.02 ; RMSEA: 0.07. ${ }^{\star} p<0.01$; ${ }^{* *} p<0.05 ;{ }^{* * *} p<0.10$. 


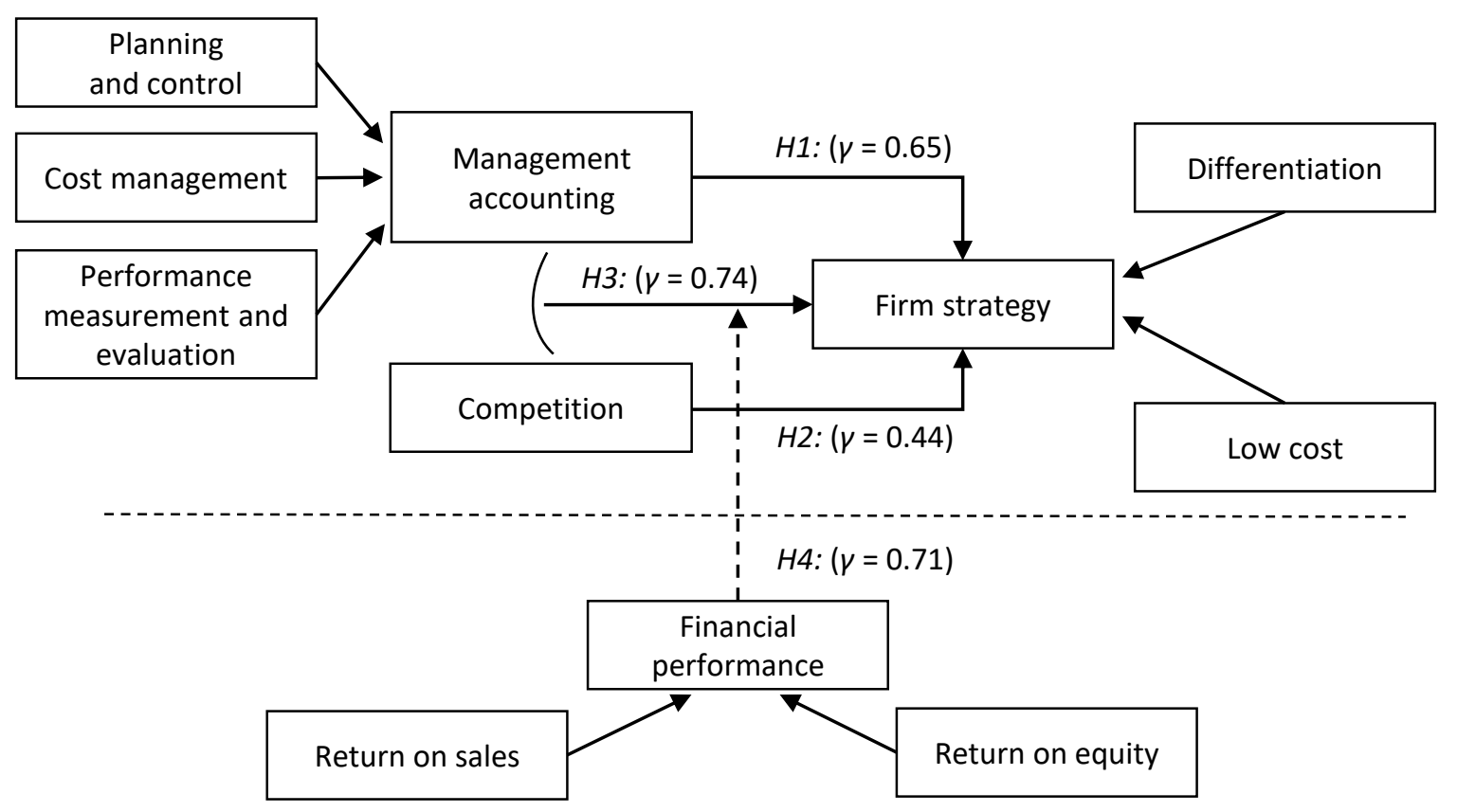

Figure 2. Tested structural model

el of competitive pressure is shifting to low-cost strategies. Financial performance influences firms' strategic choices.

Management accounting practices affect strategy selection at different levels at each firm. Depending on the data provided from the participants, companies have three categories: low, medium and high levels of adaptation (use) to management accounting applications. In the study, participants' opinions about 23 management accounting practices were asked by the five-point Likert method.
The company's adaptation score was obtained by evaluating the responses given for each company separately. According to this, companies with adaptation score between 0.1 and 1.7 use management accounting at the low level, and firms with 1.7-3.4 use intermediate level. Those with an adaptation score of 3.5 to 5 are considered at the high level. Businesses are 50\% low, 39\% medium and $28 \%$ high in management accounting applications. Table 5 shows whether there is a change in the strategy of the enterprises depending on the level of management accounting adaptation.

Table 4. Paths between sub-factors

\begin{tabular}{|c|c|c|c|}
\hline \multicolumn{2}{|c|}{ Independent variable $\rightarrow$ dependent variable } & \multirow{2}{*}{$\frac{\boldsymbol{\beta}}{0.39^{* *}}$} & \multirow{2}{*}{$\frac{\text { Hypotheses outcome }}{\text { H1a: accepted }}$} \\
\hline Planning and control & Differentiation & & \\
\hline Cost management & Differentiation & $0.36^{* *}$ & H1b: accepted \\
\hline Performance measurement and evaluation & Differentiation & 0.12 & H1c: rejected \\
\hline Competition & Differentiation & $0.41^{* *}$ & H2a: accepted \\
\hline Planning and control & Low cost & $0.42^{* *}$ & H1d: accepted \\
\hline Cost management & Low cost & $0.48^{* *}$ & H1e: accepted \\
\hline Performance measurement and evaluation & Low cost & $0.24^{* * *}$ & H1f: accepted \\
\hline Competition & Low cost & $0.48^{* *}$ & H2b: accepted \\
\hline Return on sales & Differentiation & $0.20^{* * *}$ & - \\
\hline The return on equity & Differentiation & $0.22^{* * *}$ & - \\
\hline Return on sales & Lower costs & $0.25^{* * *}$ & - \\
\hline The Return on equity & Lower costs & $0.28^{* * *}$ & - \\
\hline
\end{tabular}

Note: ${ }^{*} p<0.01,{ }^{* *} p<0.05,{ }^{* * *} p<0.10$. 
Table 5. Changes in company strategies according to the level of adaptation to management accounting

\begin{tabular}{|c|c|c|c|c|c|c|c|}
\hline \multirow{2}{*}{ Variable } & \multicolumn{2}{|c|}{ High level } & \multicolumn{2}{|c|}{ Intermediate level } & \multicolumn{2}{|c|}{ Low level } & \multirow{2}{*}{ Significance } \\
\hline & $R^{2}, \%$ & $\gamma$ & $R^{2}, \%$ & $Y$ & $R^{2}, \%$ & 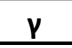 & \\
\hline Management accounting practices & 59 & 0.70 & 50 & 0.62 & 44 & 0.51 & $0.02^{* *}$ \\
\hline Competition & 35 & 0.49 & 28 & 0.30 & 23 & 0.34 & $0.09^{* * *}$ \\
\hline
\end{tabular}

Note: ${ }^{*} p<0.01,{ }^{* *} p<0.05,{ }^{* *} p<0.10$.

According to Table 5, the adaptation to management accounting practices more effectively affects the determination of firm strategies as the use of management accounting in operations with respect to adaptation level. In terms of intensity of competition, strategies change significantly according to the level of using management accounting.

\section{DISCUSSIONS AND CONCLUSION}

This research conducted on SME was aimed to determine the direct and joint effects of management accounting and competition on strategy development. Management accounting practices pave the way for more efficient and productive sustainability of planning and control activities and influence the company's choice of low-cost strategy or differentiation strategies. The management accounting determines the closeness of the strategies to the expectations through the performance measurement and evaluation function and gives an idea about the measures to be taken in the decision-making. Competition affects the operational processes of the SMEs and the market share. The conclusions and implications of the research because of the analyses made according to the findings obtained in the research are as follows.

1. The planning and control functions of management accounting practices result in enterprises adopting low-cost strategies. Production costs are positively developing as planning and control applications are preferred by the enterprise. This is through the reduction of development costs, the elimination of non-value-generating cost items, and the potential benefit of designing the product in the most cost-volume-profit cycle. Therefore, the low-cost strategy is becoming a priority. Management accounting practices enable a firm to perform cost management more accurately, thereby increasing the success of operations.

2. The performance measurement and evaluation function of management accounting applications affect corporate strategies. Measuring and evaluating performance contributes to identifying missing and incorrect strategic steps and tactics and developing solutions. The methods of management accounting such as break-even analysis, profitability analysis, stock value analysis, sales analysis and benchmarking show whether the strategies and objectives of the firm are optimal or not. By showing the difference between the performance measurement expectation and the actual situation, it helps decision makers to choose the right steps and strategic priorities.

3. The total variance of impacts of management accounting practices on the strategies was $54 \%$. Management accounting plays a very important and critical role given that strategy development is influenced by internal and external factors.

4. Competition has many positive and negative effects. The results of the research show that the effect of competition on strategic decisions and options is significant and is realized at $31 \%$ of the variance. Competition has a direct impact on companies choosing between differentiation or low-cost strategies.

5. One of the most important contributions and results of the research is to gain the literature by producing the management accounting adaptation (level of use) score of the firm. Using the data 
obtained from the companies, the usage level of management accounting applications determined for each company is scored with a value between 0 and 5 and divided into categories. Through this score, it is easy to determine whether the management adheres to the management accounting practices at low, intermediate or high level. The results also confirm the strategies in which the level of use of managerial accounting is increased by firms when their score was high or low.

Suggestions developed for researchers, managers, accountants and other practitioners in the light of the results and inferences in the research are as follows: the use of modern methods with traditional approaches in management accounting should become widespread. Accurate measurement and evaluation of performance in businesses will have a significant impact on rational strategic options and practices. In this context, performance measures such as sales analysis, profitability analysis, stock value analysis should not be neglected by SMEs. Competition can create hazards for firms, as well as opportunities. Research findings show that the functionality of competitive surplus management accounting practices and strategic decisions of firms increases. It will be an important administrative objective to understand competition and integrate the teaching effect of competition into the accounting process of the companies. Management accounting does not only refer to a system of making a decision, but also provides clues to the future. In this context, management strategies should be defined and utilized from the information production function of the management accounting. The existence of factors such as the lack of motivation and the limited availability of entrepreneurs' willingness to participate in the questionnaire led to this study being conducted in a small sample. In the studies that will be carried out as the continuation of the research topic, the sample size should be widened to cover more firms. This will increase your chances of doing comparative analyses on strategy development.

\section{REFERENCES}

1. Abdel Al, S. F. A., \& McLellan, J. D. (2013). Strategy and management accounting practices alignment and its effect on organizational performance. Journal of Accounting, Business \& Management, 20(1), 1-27. Retrieved from https://web.a.ebscohost.com/ab stract?direct $=$ true\&profile $=$ ehos t\&scope $=$ site\&authtype $=$ crawle r\&jinl $=0216423 X \& A N=870027$ 88\&h=yL9bwTl0ZqtHeXnpkU1 15PbRD6WcihMpQnLS8eEQK uuWs1GVESPFZtHMroilKJAuTIMqiZJqMEJEZ7vg6Seeyw\%$3 \mathrm{~d} \% 3 \mathrm{~d} \& \mathrm{crl}=\mathrm{c} \&$ resultNs $=$ Ad minWebAuth\&resultLocal=ErrCrlNotAuth\&crlhashurl=login. aspx\%3fdirect $\% 3$ dtrue $\% 26$ profile\%3dehost $\% 26$ scope\%3dsite\%26authtype\%3dcrawler\%26jrnl\%3d0216423X\%26AN\%3d87002788

2. Abraham, A., Glynn, J., Murphy, M., \& Wilkinson, B. (2008). Accounting for managers. London: Cengage Learning EMEA.

3. Acquaah, M., \& Yasai-Ardekani, $M$. (2008). Does the implementation of a combination competitive strategy yield incremental performance benefits? A new perspective from a transition economy in Sub-Saharan Africa. Journal of Business Research, 61(4), 346-354. https://doi.org/10.1016/j. jbusres.2007.06.021

4. Alnawaiseh, M. A. L. I. (2013). The extent of applying strategic management accounting tools in Jordanian banks. International Journal of Business and Management, 8(19), 32-44. https:// doi.org/10.5539/ijbm.v8n19p32

5. Anderson, S. W., \& Lanen, W. N. (1999). Economic transition, strategy and the evolution of management accounting practices: the case of India. Accounting Organizations and Society, 24(5-6), 379-412. https://doi.org/10.1016/ S0361-3682(97)00060-3

6. Angelakis, G., Theriou, N., \& Floropoulos, I. (2010). Adoption and benefits of management accounting practices: evidence from Greece and Finland. Advances in Accounting, 26(1), 87-96. https://doi.org/10.1016/j. adiac.2010.02.003
7. Atkinson, A. A., Kaplan, R. S., Matsumura, Ella Mae, Young, S. M., \& Mukherjee, A. K. (2016). Management accounting: information for decision-making and strategy execution (6th ed.). Boston: Pearson.

8. Baines, A., \& Langfield-Smith, K. (2003). Antecedents to management accounting change: a structural equation approach. Accounting, Organizations and Society, 28(7-8), 675-698. https://doi.org/10.1016/S03613682(02)00102-2

9. Baird, K. M., Harrison, G. L., \& Reeve, R. C. (2004). Adoption of activity management practices: a note on the extent of adoption and the influence of organizational and cultural factors. Management Accounting Research, 15(4), 383399. https://doi.org/10.1016/j. mar.2004.07.002

10. Box, T. M., \& Miller, W. D. (2011). Small-firm competitive strategy. Academy of Strategic Management Journal, 10(2), 55-59. Retrieved from https://www.researchgate. 
net/publication/298693813_Smallfirm_competitive_strategy

11. Bryson, J. R., \& Lombardi, R. (2009). Balancing product and process sustainability against business profitability: Sustainability as a competitive strategy in the property development process. Business Strategy and the Environment, 18, 97-107. https://doi.org/10.1002/ bse. 640

12. Cadez, S., \& Guilding, C. (2008). An exploratory investigation of an integrated contingency model of strategic management accounting. Accounting, Organizations and Society, 33(7-8), 836-863. https:// doi.org/10.1016/j.aos.2008.01.003

13. Chenhall, R. H., \& LangfieldSmith, K. (1998). Adoption and benefits of management accounting practices: an Australian study. Management Accounting Research, 9(1), 1-19. https://doi.org/10.1006/ mare.1997.0060

14. Cuganesan, S., Dunford, R., \& Palmer, I. (2012). Strategic management accounting and strategy practices within a public sector agency. Management Accounting Research, 23(4), 245 260. https://doi.org/10.1016/j. mar.2012.09.001

15. Jansen, J. J. P., Van Den Bosch, F. A. J., \& Volberda, H. W. (2006). Exploratory innovation, exploitative innovation, and performance: Effects of organizational antecedents and environmental moderators. Management Science, 52(11), 1661-1674. https://doi. org/10.1287/mnsc. 1060.0576

16. Juras, A. (2014). Strategic management accounting-what is the current state of the concept? Economy Transdisciplinarity Cognition, 17(2), 76-83. Retrieved from http://www.ugb. ro/etc/etc2014no2/13_Juras_A. pdf

17. Oboh, C. S., \& Ajibolade, S. O. (2017). Strategic management accounting and decision making: A survey of the Nigerian banks. Future Business Journal, 3(2), 119-137. https://doi. org/10.1016/j.fbj.2017.05.004

18. Parners, D. (2011). Competitive strategies and exit decisions in oligopolies. Journal of MultiDisciplinary Research, 3(2), 43-65.

19. Rickwood, C. P., Coates, J. B., \& Stacey, R. J. (1990). Stapylton: Strategic management accounting to gain competitive advantage. Management Accounting Research, 1(1), 37-49. https://doi.org/10.1016/S10445005(90)70044-3

20. Widener, S. K. (2007). An empirical analysis of the levers of control framework. Accounting Organizations and Society, 32(7-8), 757-788. https://doi. org/10.1016/j.aos.2007.01.001

21. Yan, S. (2010). Competitive strategy and business environment: The case of small enterprises in China. Asian Social Science, 6(11), 64-71. https://doi. org/10.5539/ass.v6n11p64 